INDEPENDENT JOURNAL OF MANAGEMENT \& PRODUCTION (IJM\&P)

http://www.ijmp.jor.br

v. 6, n. 1, January - March 2015

ISSN: 2236-269X

DOI: 10.14807/ijmp.v6i1.197

\title{
OVERVIEW OF INTERNATIONAL PUBLICATIONS ON THE INNOVATION PROCESS: A BIBLIOMETRIC STUDY
}

\author{
Rodrigo Marques de Almeida Guerra \\ Universidade de Caxias do Sul (UCS), Brazil \\ E-mail: rmaguerra@ucs.br \\ Márcia Almeida Chiappin \\ Universidade de Caxias do Sul (UCS), Brazil \\ E-mail: marcia.chiappin@gmail.com \\ Rodrigo Borges Bertoni \\ Universidade de Caxias do Sul (UCS), Brazil \\ E-mail: rbberton@gmail.com \\ Pelayo Munhoz Olea \\ Universidade de Caxias do Sul (UCS), Brazil \\ E-mail: pelayo.olea@gmail.com \\ Eric Charles Henri Dorion \\ Universidade de Caxias do Sul (UCS), Brazil \\ E-mail: edorion@ucs.br \\ Submission: $13 / 02 / 2014$ \\ Revision: 25/02/2014 \\ Accept: 01/07/2014
}

\section{ABSTRACT}

Bibliometric Studies concepts. There were five stages for the configuration of this article: identification of the keyword, Innovation Process, and selection of the search criteria; selection of articles and listing them according to the number of citations under the search criteria; selection of the ten articles with the highest number of citations; analysis of the selected articles; and discussion about the conclusions. The study makes it possible to identify which are the main published articles on Innovation Process based on the number of citations, length of time and date, countries, areas of knowledge, journals, authors and universities of publication. According to the findings, it seems advisable for developing countries' scholars to foster further research on Innovation Process, as well as more productions on Bibliometric Research as a whole.

[http://creativecommons.org/licenses/by/3.0/us/]

Licensed under a Creative Commons Attribution 3.0 United States License 
Keywords: Bibliometric Research. Innovation Process. Scopus data-base

\section{INTRODUCTION}

Innovation is not simply designing a good idea (TIDD; BESSANT; PAVITT, 2008), but a process of organization which is constituted by "search, discovery, development, improvement, adoption and commercialization of new processes, products, organizational structures and procedures" (TEECE; JORDE, 1990, p 76).

However, an invention cannot be classified as an example of innovation unless it has one of the five characteristics proposed by Schumpeter (1985), as follows: introduction of a new good; introduction of a new production method (which has not yet been tested); opening of a new consumer market; conquest of a new source of raw materials, supplies and/or semi-manufactured goods; and establishment of a new organization (which is able to become competitive in the market).

Thus, innovation is a process that should emphasize the practical use (TIDD; BESSANT; PAVITT, 2008), and, as consequence, enable organizations to become more competitive (PITELIS; TEECE, 2009), such as what happens with the formation of strategic alliances for cooperation, innovation and competition among stakeholders (TEECE, 1992).

Recent research has investigated the application of bibliometric studies on topics related to innovation, such as: open innovation (WANG; TANG, 2013), innovation based on Schumpeter (LAZZAROTTI ;DALFOVO; HOFFMANN, 2011), innovation in cooperative relations (LOPES; CARVALHO, 2012), national innovation systems (TEIXEIRA, 2014), social networks on innovation (CORREA; RIBEIRO, 2013), Bibliometric Research, geoanalysis and social networks (FRANCISCO, 2013). Innovation is a fairly investigated topic. However, there seems to be very few published bibliometric studies about the subject.

In this context, it is easy to see that the theme Innovation Process requires further investigation. The overall objective of this work is to analyze the top ten international publications, by doing a bibliometric research on the theme Innovation Process. Thus, we intend to find solutions for the following problem: What is the theoretical panorama in major international publications about innovation process? 
DOI: 10.14807/ijmp.v6i1.197

Having stated this objective, the research was carried out through Scopus database in order to identify the main journals, authors, universities, document types, countries with higher representativeness of publication as well as the areas of knowledge that more publish from the keyword Innovation Process.

Besides this introductory part, this paper is structured in five sections: Literature Review, Methodology and Research Development, Research Results and Conclusion.

\section{LITERATURE REVIEW}

This section aims at conceptualizing Innovation, Innovation Process and Bibliometric Research.

\subsection{Innovation}

Innovation extends beyond the conception of a new idea. It ranges from the practical use (TIDD; BESSANT; PAVITT, 2008) to complexity, risk-taking, management requirements and alignment with the consumer market (BESSANT; TIDD, 2009) and its stakeholders (LAWSON; SAMSON, 2001), enabling the formation of a new strategy for the firm (WINTER, 2003).

Innovative Process states that economic development can happen in five different manners, as follows: introduction of a new product or qualitative changes in existing product, a process innovation that is new to an industry, opening of a new market, development of new source supplies of raw materials and other inputs, and changes in industrial organization (SCHUMPETER, 1985).

Thus, one can define innovation as the implementation of a product (good or service) new or significantly improved, or a process, or a new marketing method, or a new organizational method in business practices, regarding the organization of the work environment or external relations (FINEP, 2004).

Differentiation of organizations will only be achieved through company creation of values, knowledge acquisition, intangible assets and other advantages / capabilities for obtaining innovation (PITELIS; TEECE, 2009), as well as infrastructure for continuous improvement (ANAND et al., 2009) aiming at the growth of the firm (SCHUMPETER, 1985). 
DOI: 10.14807/ijmp.v6i1.197

So in order for organizations to accomplish innovation, they have to see it as a flexible, organizational and strategic process which is constituted by dynamic capabilities (EISENHARD; MARTINS, 2000). Therefore, innovation can be understood as being of high nature, able to configure multiple abilities (LAWSON; SAMSON, 2001).

\subsection{Innovation Process}

Innovation Process is a usual practice involving search, selection and implementation elements (TIDD; BESSANT; PAVITT, 2008), and it can foster many benefits to an organization, such as competitive advantage (BAER; FRESE, 2003), which makes it fundamental to competition analysis (TEECE, 1992).

Innovation, as a rule, can be seen from two points of view: incremental and radical innovation. Incremental innovation is observed when making minor improvements in products, services or existing processes (BESSANT; TIDD, 2009). This kind of innovation doesn't generate much impact when compared to radical innovation, but it is as necessary as the radical processes, since it is more commonly developed by organizations (as seen in in the automobile industry) (BES; KOTLER, 2001).

Christensen (2001) deals with the innovation break, demonstrating that the market-leading organizations adopt the strategy of listening to their customers, aiming to use the feedback in the application of gradual and incremental innovations in their processes.

Fichman and Kemerer (1997) suggest that organizations need to innovate even in the presence of knowledge barriers, or even if the burden of organizational learning is effectively lower, or even if much of the know-how is already applied by the organization or because such knowledge can be acquired more easily or economically.

Utterback and Abernathy (1975) developed an empirical investigation on the existence of patterns of innovation between product development and production processes through the analysis of five different industrial segments. The survey results concluded that there is a positive relationship between the ability of a firm to innovate, its competitive strategy and management of production resources. 
DOI: 10.14807/ijmp.v6i1.197

Von Hippel (1976) conducted a study on a sample of one hundred and eleven instruments of scientific innovation in order to determine the role of product users and their manufacturers regarding the innovation process. The research concluded that the industry was considered innovative (for eighty percent of the sample), but the companies that are part of the sample weren't innovative, but providers of product and production engineering for the innovative industries which use devices.

\subsection{Bibliometric Research}

A bibliometric study consists of quantitative and statistical technique which allows the measurement of scientific production rates in order to disseminate academic knowledge (ARAÚJO, 2006; HID; NASCIMENTO; OLIVEIRA, 2012). Bibliometry aims to count and measure things through the analysis of publications, citations and co-citations (CRONIN, 2001), allowing the measurement of quality in publications, the impact on different academic levels (GLANZEL et al., 2006), trends in International publishing (SMITH; HAZELTON, 2008), country, territory, document types, languages and publishing area (TSAI, 2013).

Therefore, Bibliometric Research contributes to the identification of pi authors, allowing the construction of a scientific knowledge diffusion network (URBIZAGÁSTEGUI-ALVARADO, 1984). Bibliometric Research is considered scientific valid for tracking citations in academic journals; understanding the past to predict the future, and analysing large amounts of historical data to help researchers in the formation of hidden patterns (DAIM et al., 2006). Other advantages of using Bibliometric Research are related to research evaluation in universities, research groups, identification of key academics, ranking among institutions (HAYASHI et al., 2007), number and frequency of previous publications, chronological organization of journals, access to research grants (TSAl, 2013) among others.

Glanzel et al. (2006) emphasize the contribution of citation analysis in bibliometric studies (considered as an element of reward), but the author highlights that self-citation can generate distortions generating forgery of the research impact. Thus, endogenous excessive use of self-citations or reference to the program itself) can distort the bibliometric research indicators (CALDAS; TINOCO, 2004; GLANZEL et al., 2006). 
DOI: 10.14807/ijmp.v6i1.197

For this reason bibliometric methods should be used with limitations and jointly with other indicators (HAYASHI et al., 2007). Some disadvantages of Bibliometric Research are "time, cost, error data collection, publications and quotes practice varied which make comparisons difficult as well as propensity to self-citations by scientists and research groups" (HAYASHI et al., 2007, p 05).

Bibliometric research is based on three fundamental laws: Lotka's, Bradford's and Zipf's (URBIZAGÁSTEGUI-ALVARADO, 1984; ARAÚJO, 2006; HID; NASCIMENTO; OLIVEIRA, 2012; ARSENOVA 2013).

Lotka's law is considered a method of measuring authors productivity, it was formulated in 1926 (URBIZAGÁSTEGUI-ALVARADO, 1984; ARAÚJO, 2006). It considers that a large proportion of academic research is produced by a limited number of authors. However, they constitute a small share of scientific production (MENDONÇA NETO; RICCIO; SAKATA, 2009; HID; NASCIMENTO; OLIVEIRA, 2012).

Therefore, the law of Lotka stablishes through the inverse square that the number of authors who perform $\mathbf{n}$ contributions to a particular field of knowledge is about $1 / \mathbf{n}^{2}$ of those making just one contribution, however the percentage of those that generate only one contribution is of about 60\% (URBIZAGÁSTEGUIALVARADO, 2002).

Part of the criticism made to Lotka's law is related to the contradictions and conflicts in research results (URBIZAGÁSTEGUI-ALVARADO, 2002), difficulties in parameter estimation due to misuse of bondage tests (goodness-of-fit tests) (CHEN, 1989), non-uniformity in the organization and identification of data, as well as in allocating the number two to $\mathbf{n}$ indiscriminately (PAO, 1985).

However, Lotka's law presents some great contributions, such as the generalization of the inverse relation (NATH; JACKSON, 1991) existing between the frequency of authors which implies the originality of the Law (PAO, 1985); investigation of the frequency of double or triple co-authors share (KRETSCHMER; KRETSCHMER, 2007), the number of times an approach is used to identify influential variables associated with the empirical data (CHEN, 1989), and use of data mining (TSAl, 2013). 
DOI: 10.14807/ijmp.v6i1.197

Known as the law of scientific knowledge dispersion, Bradford's Law was first published in 1934, and is considered the most popular of all. It consists of dividing the articles into three zones or cores of readers, each one containing a third of the total representative articles. The first group is represented by a few journals, with high productivity. The second core, considered intermediate has a greater number of journals, however, less productive ones. The third core has a higher amount of publications, though with even less productivity (ARAÚJO, 2006; HID; NASCIMENTO; OLIVEIRA, 2012; ARSENOVA 2013).

For the application of Bradford's Law it is necessary to perform the multiplied Bradford calculation $\left(B_{m}\right)$ from the ratio of the number of journals in any zone by the number of journals in the previous one. This calculation allows us to infer that the number of areas is inversely proportional to $B_{m}$ (ARAÚJO, 2006).

The application of Bradford's Law in the Brazilian bibliometric production is considered high (of 78 works produced from 1972 to $1983,50 \%$ applied this law). The main contribution is the formulation of basic lists of journals in various areas of academic knowledge (URBIZAGÁsTEGUI-ALVARADO, 1984).

Zipf's Law describes that the frequency in the use of words in a given text (URBIZAGÁSTEGUI-ALVARADO, 1984) was established in 1949 through the correlation between the number of different words and the repetition of their use (ARAÚJO, 2006; HID; NASCIMENTO; OLIVEIRA, 2012).

Zipf's Law analyzes if the relationship among words in a given text is large enough, by counting them on a large scale (ARAÚJO, 2006). The application of Zipf's Law is performed by listing the occurrence of words in a given text, ordering them in decreasing order. The multiplication of word position ( $r$ ) by its frequency ( $\mathbf{f})$ must be result in a constant (k) (ARAÚJJ, 2006).

\section{METHODOLOGY AND RESEARCH DEVELOPMENT}

This section aims at presenting the developmental stages of this article. The method of study and the stages of data collection are detailed below.

\subsection{Method of Study}

This research follows a descriptive quantitative method together with Bibliometric Research. Bibliometric Research considers scientific publications with 
DOI: 10.14807/ijmp.v6i1.197

the purpose of establishing patterns, relationships, and trends on a particular topic being researched (IKPAAHINDI, 1985). This kind of research seeks to identify the most relevant journals, prominent subjects, key research areas, and origin of authors and universities related to the topic discussed (PRASAD; TATA, 2005). Bibliometric Research is considered quantitative as it involves aspects related to the production, dissemination and use of the information recorded, and It was used for the first time in 1969 (MACIAS-CHAPULA, 1998).

The quantitative research requires statistical treatment to prevent distortions in the analysis and interpretation of results (DIEHL, 2004). On the other hand, descriptive research uses standardized data collection techniques, in order to describe the characteristics of certain populations or phenomena (GIL, 2008).

The article was developed through a research conducted in the Scopus database, using $100 \%$ of the data acquired through the steps outlined in Table 1 . We opted for the Scopus database for being a metasearch which enables the obtainment of various articles contained in other databases simultaneously. The choice for international publications is due to the fact that they possess greater impact on future national publications.

Data collection occurred in November 2013, the keyword innovation process was used in order to identify which are the main journals that deal with the theme, most cited authors, titles of publications, temporal distribution of publications, major countries, areas of knowledge etc..

\subsection{Stages for Data Collection}

The keyword used in the research process was Innovation, the criterion Article Title was selected for the fulfillment of the first stage. Subsequently, the articles were chosen according to the criterion Number of Citations (Cited by) as shown in Table 1.

\begin{tabular}{c|l}
\hline Stages & Action performed \\
\hline $1^{\mathrm{a}}$ & $\begin{array}{l}\text { Search by topic } \\
\text { Topic = (Process Innovation) } \\
\text { In = (Article Title) }\end{array}$ \\
\hline $2^{\mathrm{a}}$ & $\begin{array}{l}\text { Selection of articles for the largest number of citations } \\
\text { Sort by = (Cited by) }\end{array}$ \\
\hline $3^{\mathrm{a}}$ & Marking the first ten articles for conducting the research \\
\hline $4^{\mathrm{a}}$ & Reading of selected articles. \\
\hline $5^{\mathrm{a}}$ & Analysis and discussion of research findings. \\
\hline \multicolumn{1}{c}{ Source: prepared by the authors }
\end{tabular}

Source: prepared by the authors 
DOI: 10.14807/ijmp.v6i1.197

The third step consisted in selecting the first ten articles considered most relevant to the research, as shown in Table 2. The fourth stage took into consideration the reading of selected articles (keywords, abstract, country of publication, universities, document types, authors etc.). The fifth stage was the analysis and discussion of research findings.

Table 2: Central articles about Innovation process

\begin{tabular}{|c|c|c|c|}
\hline Authors (year) & Title of the publication & Journal & $\begin{array}{l}\text { Numbers of } \\
\text { citations }\end{array}$ \\
\hline $\begin{array}{l}\text { Utterback, J.M.; } \\
\text { Abernathy, W.J. (1975) }\end{array}$ & $\begin{array}{l}\text { A dynamic model of process } \\
\text { and product innovation. }\end{array}$ & $\begin{array}{l}\text { Omega, } 3 \text { (6), p. } \\
\text { 639-656. }\end{array}$ & 709 \\
\hline $\begin{array}{l}\text { Fichman, } \\
\text { Kemerer, C.F. (1997) }\end{array}$ & $\begin{array}{l}\text { The assimilation of software } \\
\text { process innovations: An } \\
\text { organization } \\
\text { perspective. }\end{array}$ & $\begin{array}{l}\text { Management } \\
\text { Science, } 43 \text { (10), p. } \\
\text { 1345-1363. }\end{array}$ & 311 \\
\hline $\begin{array}{ll}\text { Lynn, } & \text { G.S.; } \\
\text { J.G.; } & \text { Paulson, A.S. } \\
\text { (1996) } & \end{array}$ & $\begin{array}{l}\text { Marketing and discontinuous } \\
\text { innovation: the probe and learn } \\
\text { process. }\end{array}$ & $\begin{array}{l}\text { California } \\
\text { Management } \\
\text { Review (3), p. 8-37. }\end{array}$ & 308 \\
\hline $\begin{array}{l}\text { Benner, } \quad \text { M.J.; } \\
\text { Tushman, M. (2002) }\end{array}$ & $\begin{array}{l}\text { Process management and } \\
\text { technological innovation: a } \\
\begin{array}{l}\text { longitudinal study of the } \\
\text { photography and paint } \\
\text { industries }\end{array}\end{array}$ & $\begin{array}{l}\text { Administrative } \\
\text { Science Quarterly, } \\
47 \quad(4), \quad \text { p. } 676- \\
706+768 .\end{array}$ & 261 \\
\hline $\begin{array}{lll}\begin{array}{l}\text { Veryzer } \\
(1998)\end{array} & \text { Jr.; } & \text { R.W. } \\
\end{array}$ & $\begin{array}{l}\text { Discontinuous Innovation and } \\
\text { the New Product Development } \\
\text { Process. }\end{array}$ & $\begin{array}{l}\text { Journal of Product } \\
\text { Innovation } \\
\text { Management, } 15 \\
\text { (4), p. 304-321. } \\
\end{array}$ & 252 \\
\hline Von Hippel, E. (1976) & $\begin{array}{l}\text { The dominant role of users in } \\
\text { the scientific instrument } \\
\text { innovation process. }\end{array}$ & $\begin{array}{l}\text { Policy Research, } 5 \\
\text { (3), p. 212-239. }\end{array}$ & 230 \\
\hline $\begin{array}{l}\text { Duranton, G.; Puga, D. } \\
\text { (2001) }\end{array}$ & $\begin{array}{l}\text { Nursery cities: Urban diversity, } \\
\text { process innovation, and the life } \\
\text { cycle of products }\end{array}$ & $\begin{array}{l}\text { American } \\
\text { Economic Review, } \\
91 \quad(5), \text { p. 1454- } \\
1477 .\end{array}$ & 219 \\
\hline $\begin{array}{l}\text { Cohen, W.M.; Klepper, } \\
\text { S. (1996) }\end{array}$ & $\begin{array}{l}\text { Firm size and the nature of } \\
\text { innovation within industries: the } \\
\text { case of process and product. }\end{array}$ & $\begin{array}{l}\text { Review of } \\
\text { Economics and } \\
\text { Statistics, } 78 \text { (2), p. } \\
\text { 232-243. }\end{array}$ & 207 \\
\hline $\begin{array}{l}\text { Baer, M.; Frese, M. } \\
(2003)\end{array}$ & $\begin{array}{l}\text { Innovation is not enough: } \\
\text { Climates for initiative and } \\
\text { psychological safety, process } \\
\text { innovations, and firm } \\
\text { performance. }\end{array}$ & $\begin{array}{l}\text { Journal of } \\
\text { Organizational } \\
\text { Behavior, } 24(1), p . \\
45-68 .\end{array}$ & 193 \\
\hline Gassmann, O. (2006) & $\begin{array}{l}\text { Editorial: Opening up the } \\
\text { innovation process: Towards } \\
\text { an agenda. }\end{array}$ & $\begin{array}{lr}\mathrm{R} \quad \text { and } & \mathrm{D} \\
\text { Management, } & 36 \\
(3), \text { p. 223-228. } & \end{array}$ & 172 \\
\hline
\end{tabular}

Source: prepared by the authors

\section{RESEARCH RESULTS}

The publications analyzed dated from 1975 to 2006 (table 2) are considered fairly representative on the topic discussed here (709-172 citations). As shown in figure 1, the apex of publications occurred in 2011 (with 183 citations). This fact 
DOI: 10.14807/ijmp.v6i1.197

allows readers to infer that the topic is researched with plenty of visibility in recent international publications.

As seen in Figure 2 United States is the country with larger number of publications with a total of 357 publications. Germany appears in second place (185 publications). China is in third place (160 posts), followed by the UK (159 posts). Italy ranks fifth (75 publications).

The United States has more than twice the number of publications when compared to Germany which is in second place. This data shows that United States is a country which promotes research on the Innovation Process topic.

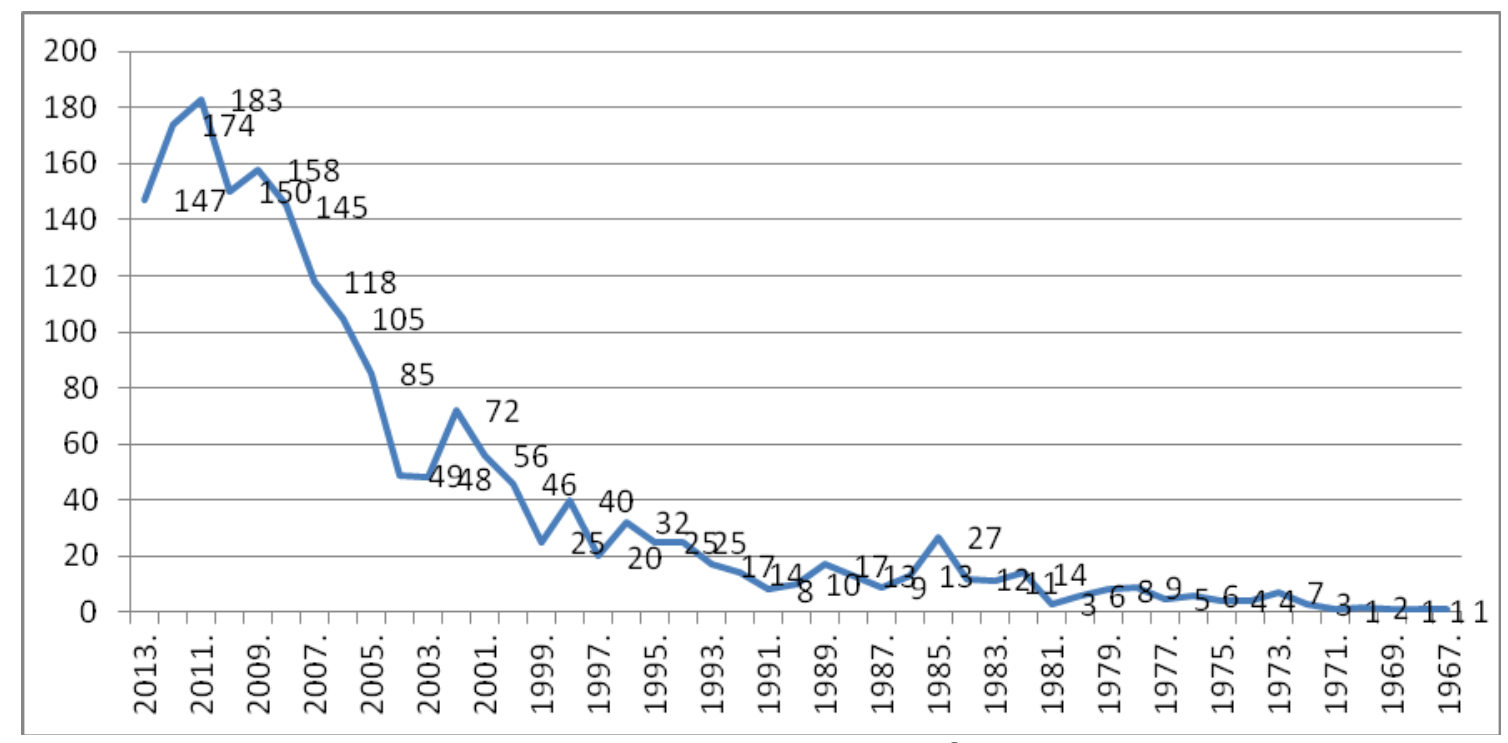

Figure 1 - Temporal distribution of publications Source: Scopus (2013)

Brazil experienced low productivity of publications on the topic of Innovation Process (with only 31 references). The same happened to India and Russia (30 and 8 publications, respectively). These are the countries that are part of the BRIC (political cooperation group formed by Brazil, Russia, India and China). This fact contributes to the generation of new research especially in developing countries.

For this research, a no restriction policy was applied to the area of knowledge for the theme of Innovation Process. The aim in applying this type of policy is to conduct an overview of the areas of greatest incidence of publications about a topic. This type of search helps to promote new research in various areas of knowledge that have great possibility for growth which can be demonstrated in the areas of medicine, pharmacy, energy, computer science, materials science (as figure 03). 
INDEPENDENT JOURNAL OF MANAGEMENT \& PRODUCTION (IJM\&P)

http://www.ijmp.jor.br

v. 6, n. 1, January - March 2015

ISSN: 2236-269X

DOI: 10.14807/ijmp.v6i1.197

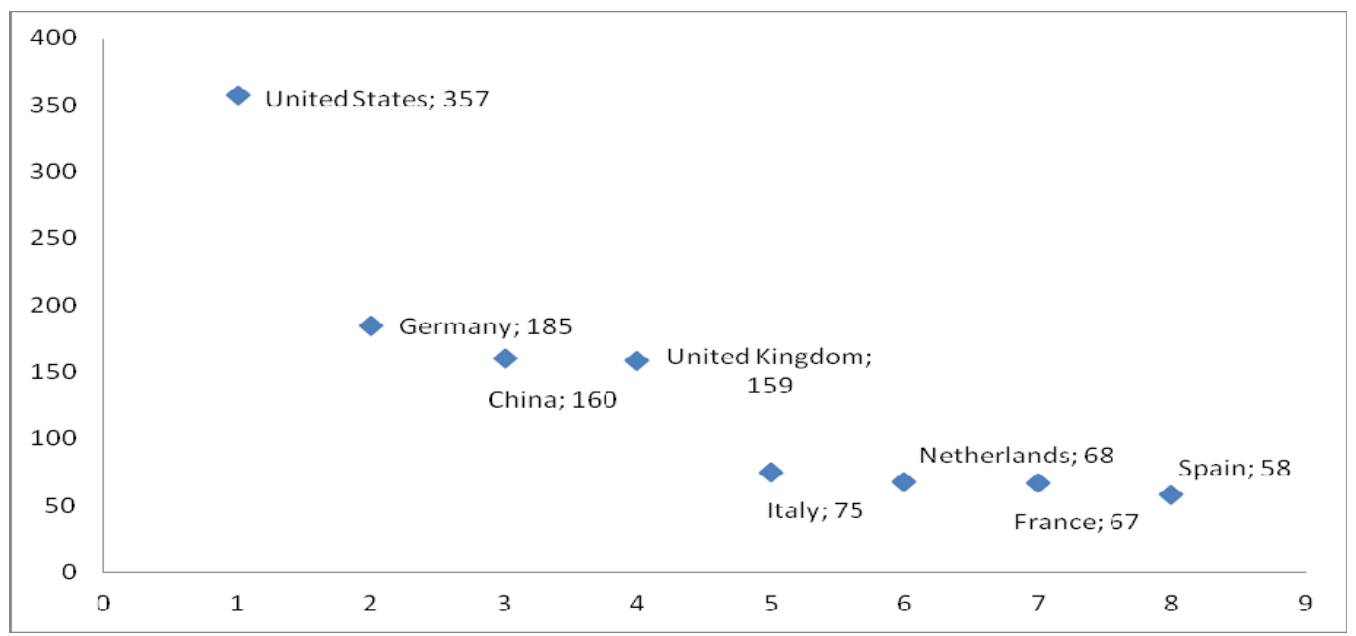

Figure 2: Publications of the origin countries

Source: Scopus (2013)

It is noticed that there is a higher concentration of publications on the subject of Innovation Process in the areas of Business, Management and Accounting, with 626 documents which demonstrates to be the area with the highest number of international publications about a topic. Right after comes the area of Engineering with 624 posts, followed by the area of Computer Science with 305 publications.

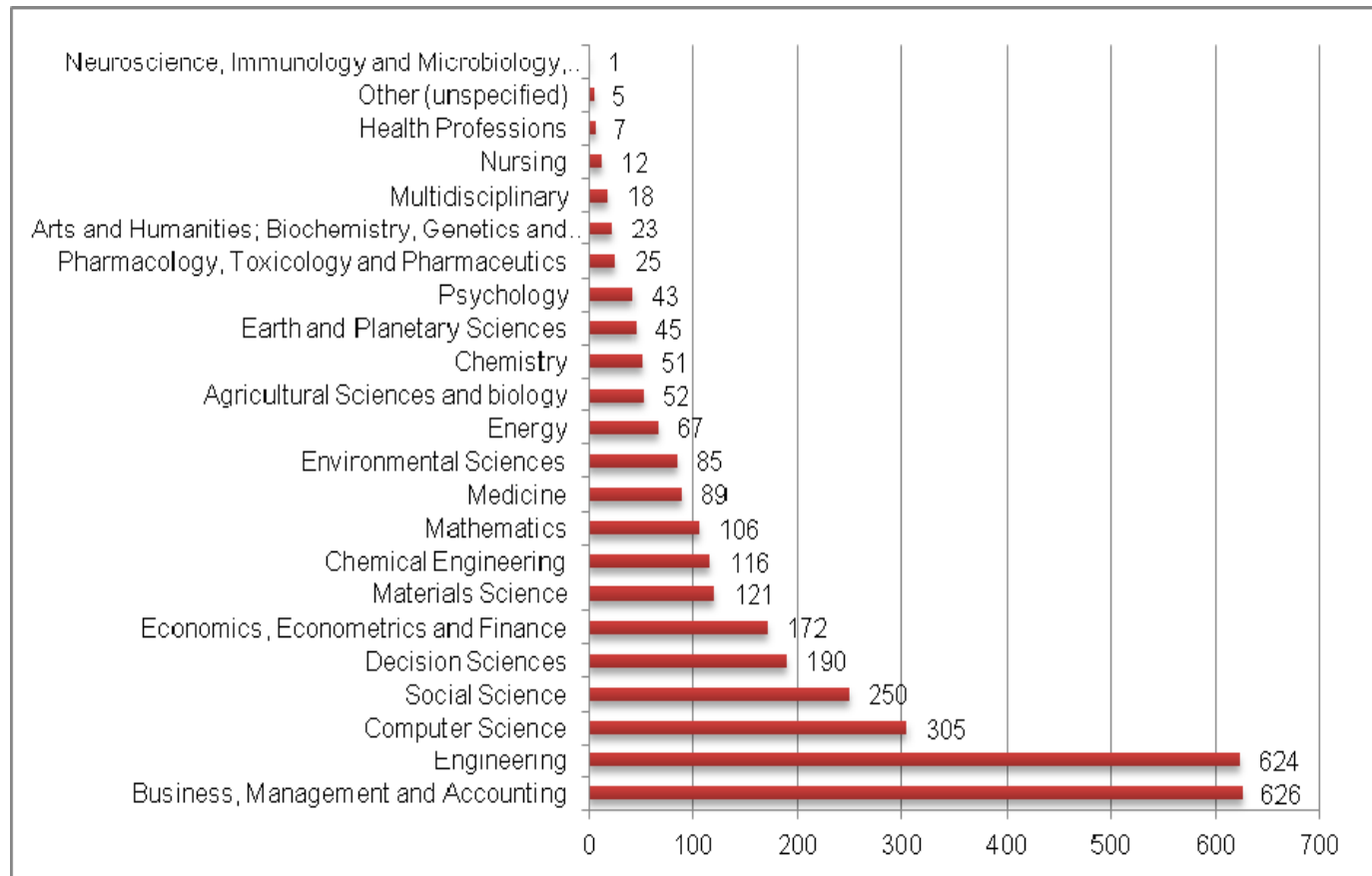

Figure 3 - Areas of knowledge Source: Scopus (2013)

As expected, the type of document most used was article (1118 documents). Paper for conference came in second with 528 publications, as shown in Figure 04. 
DOI: 10.14807/ijmp.v6i1.197

The main journals on the topic researched are open to various areas of knowledge. One reason that justifies this fact is that the concept of Innovation Process may be applied to many different areas. The top five most cited journals in bibliometric research on Innovation Process were: (1) Technovation, (2) International Journal of Technology Management, (3) Research Policy, (4) Hydrocarbon Processing, and (5) Journal of Product Innovation Management (Table 03).
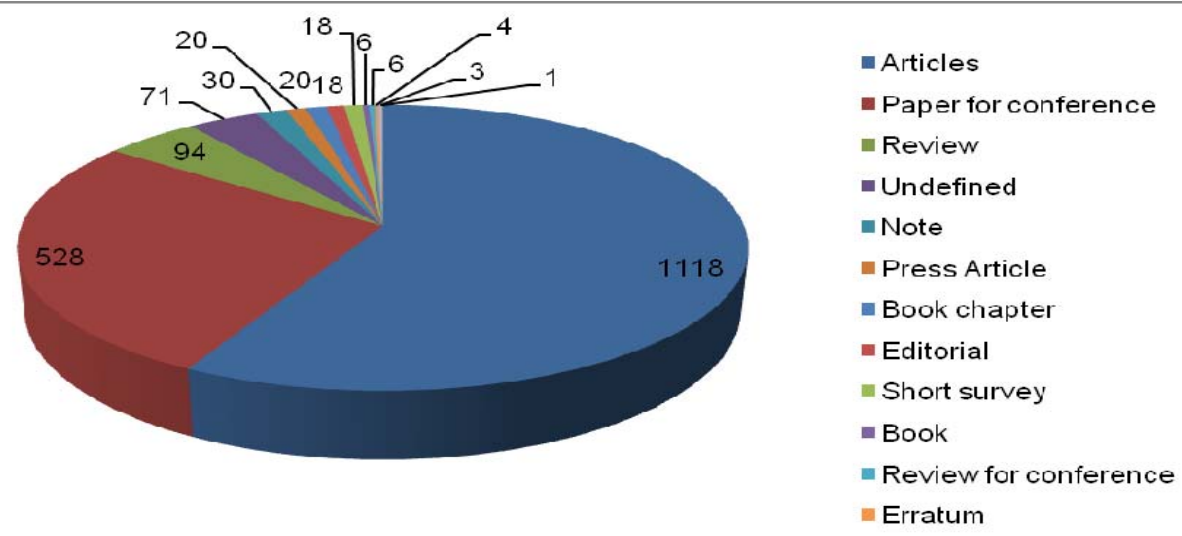

Figure 4 - Types of documents Source: Scopus (2013)

Below on tables 4 and 5 are the main authors and universities that contribute by sharing knowledge related to the topic.

Table 3: Major journals publishing

\begin{tabular}{|l|c|}
\hline Journals & $\begin{array}{c}\text { Number of } \\
\text { Publications }\end{array}$ \\
\hline Technovation & 28 \\
\hline International Journal of Technology Management; Research Policy & 20 \\
\hline Hydrocarbon Processing; Journal of Product Innovation Management & 17 \\
\hline R and D Management & 16 \\
\hline Technology Analysis and Strategic Management & 15 \\
\hline \begin{tabular}{l} 
IEEE Transactions on Engineering Management \\
\hline $\begin{array}{l}\text { European Journal of Innovation Management; International Journal of Innovation } \\
\text { Management }\end{array}$
\end{tabular} & 14 \\
\hline $\begin{array}{l}\text { IEEE International Engineering Management Conference; Technological } \\
\text { Forecasting and Social Change; Lecture Notes in Computer Science Including } \\
\text { Subseries Lecture Notes in Artificial Intelligence and Lecture Notes in } \\
\text { Bioinformatics }\end{array}$ & 11 \\
\hline $\begin{array}{l}\text { ZWF Zeitschrift Fuer Wirtschaftlichen Fabrikbetrieb; Quality Access to Success; } \\
\text { Advanced Materials Research }\end{array}$ & 10 \\
\hline $\begin{array}{l}\text { Proceedings of the Annual Hawaii International Conference on System Sciences; } \\
\text { Picmet Portland International Center for Management of Engineering and } \\
\text { Technology Proceedings. }\end{array}$ & 9 \\
\hline $\begin{array}{l}\text { International Journal of Entrepreneurship and Innovation Management; Journal of } \\
\text { High Technology Management Research. }\end{array}$ & 8 \\
\hline
\end{tabular}




\section{INDEPENDENT JOURNAL OF MANAGEMENT \& PRODUCTION (IJM\&P)}

http://www.ijmp.jor.br

v. 6, n. 1, January - March 2015

ISSN: 2236-269X

DOI: 10.14807/ijmp.v6i1.197

Actual Problems of Economics; Communications in Computer and Information Science; Journal of Engineering and Technology Management Jet M; EMJ Engineering Management Journal; Journal of Technology Management and Innovation; Total Quality Management and Business Excellence; ASEE Annual Conference and Exposition Conference Proceedings; International Journal of Industrial Organization.

Management Science; International Journal of Innovation and Learning.

European Management Journal; Omega; Pharmaceutical Engineering; Proceedings of the ASME Design Engineering Technical Conference; Industrial Marketing Management; 2012 18th International Conference on Engineering Technology and Innovation ICE 2012 Conference Proceedings; 2012 Proceedings of Portland International Center for Management of Engineering and Technology Technology Management for Emerging Technologies Picmet 12; IFIP Advances in Information and Communication Technology; Espacios; International Journal of Production Research; Applied Mechanics and Materials; Energy Policy; Iced 11 18th International Conference on Engineering Design Impacting Society Through Engineering Design; Journal of Business Research; Kami Pa Gikyoshi Japan Tappi Journal; Lecture Notes in Business Information Processing.

Table 4: Main authors of publications

\begin{tabular}{|l|c|}
\hline Authors & $\begin{array}{c}\text { Number of } \\
\text { Publications }\end{array}$ \\
\hline Bi, K. & 16 \\
\hline Niehaves, B. & 9 \\
\hline Harrington, R.J.; Linton, J.D.; Anon. & 7 \\
\hline Lambertini, L.; Frishammar, J.; Lager, T.; Kumar, V.; Kumar, U.; Xing, M.; Thoben, & 5 \\
K.D.; Ottenbacher, M.C. & 4 \\
\hline Markic, M.; lida, K.; Brad, S.; Edwards, T.; Seifert, M.; Truffer, B.; Walsh, S.T. & \\
\hline Gallivan, M.J.; Ball, D.F.; Lin, L.H.; Hollomon, J.H.; Jones, O.; Dickinson, B.W.; & \\
Enkel, E.; Feng, D.; Garcia-Porres, J.; Frattini, F.; Doepker, P.E.; Karkkainen, H.; & \\
Habib, J.; Eschenbacher, J.; Cascini, G.; Chen, J.; Herbig, B.; Messnarz, R.; & \\
Moller, C.; Mustonen-Ollila, E.; Negny, S.; Newell, S.; Gassmann, O.; Nosella, A.; & 3 \\
Ortiz-Posadas, M.R.; Ai, M.Y.; Gerwin, D.; Petrovic, K.; Ren, T.; Robertson, M.; & 3 \\
Scarbrough, H.; von Hippel, E.; Schwartz, C.A.; Damanpour, F.; Parjanen, S.; & \\
Swan, J.; Tan, R.H.; Tsou, H.T.; Towler, G.P.; Gao, W.; Utterback, J.M.; & \\
Harmaakorpi, V.; Sirbu, M.A. & \\
\hline Henkel, J.; Le Lann, J.M.; Cho, W.; Gandecha, R.; Kautz, K.; Davis, J.P.; Gann, \\
D.M.; Henderson, C.; Green, G.C.; Akinola, A.A.; Honda, K.; Ligon, G.S.; \\
Fichman, R.G.; Brunswicker, S.; Duin, H.; Lin, Z.; Ikushima, Y.; Buganza, T.; \\
Bunders, J.F.G.; Bunduchi, R.; Li, W.; Garnsey, E.; During, W.E.; Cincibusova, P.; \\
Dutra, J.C.; Allen, T.J.; Inganas, M.; Kruper, J.; Li, B.Z.; Larsen, G.D.; Fischer, B.; \\
Ebeling, W.; Jha, S.; Koskinen, K.U.; Berends, H.; Kubicki, S.; Cohen, T.; Kim, \\
S.S.; Kaitin, K.I.; Berger, T.; Collins, L.; Collins, R.W.; Bergman, J.; Ansaloni, L.; \\
Dell'Era, C.; Flaig, G.; Cantarello, S.; Colomo-Palacios, R.; Liefner, I.; Bernstein, \\
B.; Li, W.H.; Arai, M.; Guan, J.; Genga, L.; Ito, H.; Aravind, D.; Capitanio, F.; \\
Guerriero, A.; Kemerer, C.F.; Kaluzny, A.D.; Hevner, A.R.; Armendariz-Inigo, J.E.; \\
Hidalgo, A.; Hsieh, P.J.; Giannakas, K.; Desouza, K.C.; Biemans, W.G.; \\
Kameoka, A.; Jimenez-Zarco, A.I.; Jin, C.; Atiemo-Obeng, V.; Dewatripont, M.; \\
Kumar, A.; Keogh, W.; King, G.H.; Biro, M.; Legardeur, J.; Hasegawa, J.; Kocher, \\
P.Y.; Johannessen, J.A.; Hatakeda, K.; Awazu, Y.; Blanco, S.; Gupta, S.; \\
Blazevic, V.; Legube, B.; Huang, J.S.; Lauenroth, H.G.; Li, X.D.; Ettlie, J.E.; Baek, \\
Y.S.; Koike, T.; Chai, K.H.; Lehmann, H. & \\
\end{tabular}


DOI: 10.14807/ijmp.v6i1.197

Table 5: Major universities of publications

\begin{tabular}{|c|c|}
\hline Universities & \begin{tabular}{|l|} 
Número de \\
Publicações
\end{tabular} \\
\hline Lappeenrannan Teknillinen Yliopisto. & 19 \\
\hline $\begin{array}{l}\text { Harbin Engineering University; Zhejiang University; Harbin University of Science } \\
\text { and Technology. }\end{array}$ & 17 \\
\hline Technische Universität München. & 15 \\
\hline $\begin{array}{l}\text { Wageningen University and Research Centre; Stanford University; Politecnico di } \\
\text { Milano; University of Cambridge. }\end{array}$ & 12 \\
\hline University of Sussex; The University of Warwick. & 11 \\
\hline Hebei University of Technology. & 10 \\
\hline Delft University of Technology. & 9 \\
\hline $\begin{array}{l}\text { University of Manchester; Luleå tekniska Universitet; MIT Sloan School of } \\
\text { Management; University of Twente; Massachusetts Institute of Technology; } \\
\text { Rensselaer Polytechnic Institute; Eidgenossische Technische Hochschule Zurich. }\end{array}$ & 8 \\
\hline $\begin{array}{l}\text { University of Amsterdam; Vrije Universiteit Amsterdam; Technische Universität } \\
\text { Berlin; Copenhagen Business School; Aalborg Universitet; Erasmus University } \\
\text { Rotterdam; Katholieke Universiteit Leuven; The University of North Carolina at } \\
\text { Chapel Hill; Manchester Business School; Universität St. Gallen; Alma Mater } \\
\text { Studiorum Università di Bologna; Aalto University. }\end{array}$ & 7 \\
\hline $\begin{array}{l}\text { University of Tokyo; Carleton University; Universidad Carlos III de Madrid; } \\
\text { Clemson University. }\end{array}$ & 6 \\
\hline $\begin{array}{l}\text { Heilbronn University; University of Colorado at Boulder; Case Western Reserve } \\
\text { University; Westfälische Wilhelms-Universität Münster; Università degli Studi di } \\
\text { Padova; Humboldt-Universität zu Berlin; University of Sheffield; Weifang } \\
\text { University; Newcastle University, United Kingdom; University of Primorska; Utrecht } \\
\text { University; CNRS Centre National de la Recherche Scientifique; Tampereen } \\
\text { Teknillinen Yliopisto; Rijksuniversiteit Groningen; Queensland University of } \\
\text { Technology; Open University; University of Texas at Austin; Aston University; } \\
\text { Universität Stuttgart; De Montfort University; National University of Singapore; } \\
\text { Maastricht University; Chongqing University; University Michigan Ann Arbor; } \\
\text { Ludwig-Maximilians-Universität München; The University of Georgia; Technische } \\
\text { Universiteit Eindhoven; Fraunhofer-Institut für System und Innovationsforschung } \\
\text { Isi.Fraunhofer.De; National Museum of Nature and Science. }\end{array}$ & 5 \\
\hline
\end{tabular}

The h-index, which quantifies the productivity and the impact of researchers based on the highest number of citations can be identified in Figure 5. The author with the highest $\mathrm{h}$ was Mills (31), followed by Kraemer (24) and Von Hippel (24) and Montoya-Weiss (21). 
DOI: 10.14807/ijmp.v6i1.197

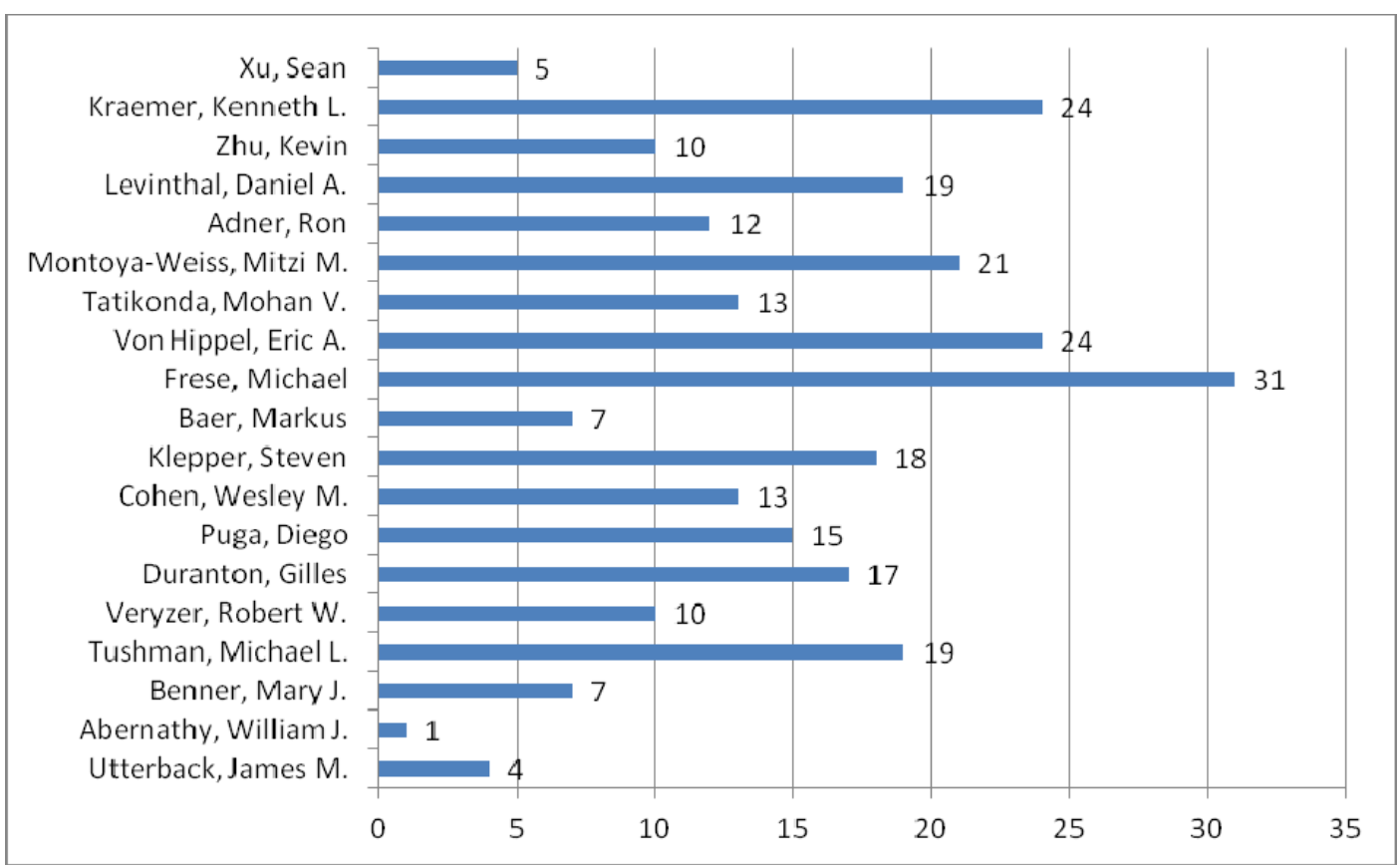

Figure 5 - $\mathrm{H}$-index of the principal authors surveyed Source: Scopus (2013)

\section{CONCLUSION}

The objective of this paper was to analyze the top ten international publications through a bibliometric research about Innovation Process. The research was carried out using the word innovation process in the Scopus database and was performed without restrictions for areas of knowledge, in other words, an overview on the topic of innovation process in leading international journals from the years 1975 to 2006 was created. Ten articles were investigated under the criteria of number of citations.

Through the research it was possible to infer that the area of knowledge with greatest publications was business, management and accounting, followed by engineering. The country with the highest number of publications was the United States, followed by Germany, China and the UK. As expected, the document type with a higher incidence of publications was article. The year with the highest number of publications was 2011, this fact shows that the subject innovation process is very current and used in recent studies in many different areas of knowledge.

The main journals responsible for publishing on the subject were Technovation (28), International Journal of Technology Management (20) and Research and Policy (20). 
DOI: 10.14807/ijmp.v6i1.197

Authors who had higher h-index were: Mills (31), Kraemer (24) and von Hippel (24) and Montoya-Weiss (21), who are also considered to be the most important authors to touch on the topic. Medicine, pharmacy, computer science and material science are other areas which were identified as important areas for new publications as well as showing great research opportunities.

At the end of this study, it is noticeable that since 2000 the international academic literature on the innovation process has been increasing constantly. It is mainly because the topic is widespread and updated, especially in developed countries. (Figure 1). This is explained by a high concentration of studies in countries like the USA, Germany, the UK, Netherlands and France (Figure 2). The incentive provided by these countries is increasing, reflecting the large number of universities that address the topic (Table 5). Analyzing the main areas of publications on the innovation process, it is easy to realize that these are important areas for the socioeconomic and financial development and infrastructure of the countries. (Figure 3 ) .

Developing countries need to increase the incentive for research on the innovation process, because they are considered basic areas to sustainable growth, economic development, public policy formation and infrastructure required for the growth of these countries. Only then, these countries may generate future gains to society as a whole. Another important point is the need to conduct new bibliometric research due to the low number of existing publications on international journals.

\section{REFERENCES}

ANAND, G.; WARD, P. T.; TATIKONDA, M. V.; SCHILLING, D. A. (2009). Dynamic capabilities through continuous improvement infrastructure. Journal of Operations Management, n. 27, p. 444-461.

ARAÚJO, C. A. (2006). Bibliometria: evolução histórica e questões atuais. Em questão, v. 12, n. 1, p. 11-32.

ARSENOVA, I. (2013). New application of bibliometrics. Procedia - Social and Behavioral Sciences, v. 73, n. 27, p. 678-682.

BAER, M.; FRESE, M. (2003). Innovation is not enough: climates for initiative and psychological safety, process innovations, and firm performance. Journal of Organizational Behavior, n. 24, p. 45-68.

BES, F. T.; KOTLER, P. (2011). A Bíblia da Inovação: Princípios fundamentais para levar a cultura da inovação contínua às organizações. São Paulo: Leya.

BESSANT, J.; TID, J. (2009). Inovação e Empreendedorismo. Porto Alegre: Bookman. 
CALDAS, M. P.; TINOCO, T. (2004). Pesquisa em gestão de recursos humanos nos anos 1990: um estudo bibliométrico. RAE - Revista de Administração de Empresas, v. 44, n. 3, p. 100-114.

CHEN, Y. (1989). Analysis of Lotka's law: the Simon-Yule approach. Information Processing \& Management, v. 25, n. 5, p. 527-544.

CHRISTENSEN, C. M. (2001). O Dilema da Inovação: Quando Novas Tecnologias Levam Empresas ao Fracasso. São Paulo: Makron Books.

CRONIN, B. (2001). Bibliometrics and beyond: some thoughts on web-based citation analysis. Journal of Information Science, v. 27, n. 1, p. 1-7.

DAIM, T. U.; RUEDA, G.; MARTIN, H.; GERDSRI, P. (2006). Forecasting emerging technologies: use of bibliometrics and patent analysis. Technological Forecasting and Social Change, v. 73, n. 8, p. 981-1012.

DIEHL, A. A. (2004). Pesquisa em ciências sociais aplicadas: métodos e técnicas. São Paulo: Prentice Hall.

EISENHARDT, K. M.; MARTIN, J. A. (2000). Dynamic capabilities: what are they? Strategic Management Journal, v. 21, n. 10-11, p. 1105-1121.

FRANCISCO, E. R. (2011). RAE-eletrônica: exploração do acervo à luz da bibliometria, geoanálise e redes sociais. Revista de Administração de Empresas, v. 51, n. 3, p. 280-306.

FICHMAN, R. G.; KEMERER, C. F. (1997). The assimilation of software process innovations: An organization learning perspective. Management Science, v. 43, n. 10, p. 1345-1363.

FINEP. (2004). Manual de OSLO: Proposta de diretrizes para coleta e interpretação de dados sobre inovação tecnológica.

GIL, A. C. (2008). Como elaborar projetos de pesquisa (4a ed.). São Paulo: Altas.

GLANZEL, W.; DEBACKERE, K.; THUS, B.; SCHUBERT, A. (2006). A concise review on the role of author self-citations in information science, bibliometrics and science policy. Scientometrics, v. 67, n. 2, p. 263-277.

HAYASHI, M. C. P. I.; HAYASHI, C. R. M.; SILVA, M. R.; LIMA, M. Y. (2007). Um estudo bibliométrico da produção científica sobre a educação jesuíta no brasil colonial. Biblios, v. 8, n. 27, p. 1-18.

HID, D. S., NASCIMENTO, C.; OLIVEIRA, D. A. (2012). Análise das publicações internacionais relacionadas ao desenvolvimento sustentável na área de administração: uma análise bibliométrica da produção científica. Administração: Ensino e Pesquisa. Rio de Janeiro, v. 13, n. 4, p. 653-671.

IKPAAHINDI, L. (1985). An overview of bibliometrics: its measurements, laws and their applications. Libri, v. 35, n. 2, p. 163-176.

KRETSCHMER, H.; KRETSCHMER, T. (2007). Lotka's distribution and distribution of co-author pairs' frequencies. Journal of Informetrics, v. 1, n. 4, p. 308-337. 
LAZZAROTTI, F.; DALFOVO, M. S.; HOFFMANN, V. E. (2011). A bibliometric study of innovation based on schumpeter. Journal of Technology Management \& Innovation, v. 6, n. 4, p. 121-135.

LAWSON, B.; SAMSON, D. (2001). Developing innovation capability in organisations: a dynamic capabilities approach. International Journal of Innovation Management, v. 5, n. 3, p. 377-400.

MACIAS-CHAPULA, C. A. (1998). O papel da informetria e da cienciometria e sua perspectiva nacional e internacional. Ciência da Informação, v. 27, n. 2, p. 134-140.

MENDONÇA NETO, O. R.; RICCIO, E. L.; SAKATA, M. C. G. (2009). Dez anos de pesquisa contábil no Brasil: análise dos trabalhos apresentados nos ENANPADS de 1996 a 2005. RAE - Revista de Administração de Empresas, v. 49, n. 1, p. 62-73.

NATH, R.; JACKSON, W. M. (1991). Productivity of management information systems researchers: Does Lotkas's law apply? Information Processing \& Management, v. 27, n. 2-3, p. 203-209.

PAO, M. L. (1985). Lotka's law: a testing procedure. Information Processing \& Management, v. 21, n. 4, p. 305-320.

PITELIS, C. N.; TEECE, D. J. (2009). The (new) nature and essence of the firm. European Management Review, v. 6, n. 1, p. 5-15.

PRASAD, S.; TATA, J. (2005). Publications patterns concerning the role of teams/groups in the information systems literature from 1990 to 1999. Information \& Management, v. 42, n. 8, p. 1137-1148.

SCHUMPETER, J. A. (1985). Teoria do desenvolvimento econômico: uma investigação sobre lucros, capital, crédito, juro e ciclo econômico (2a ed.). São Paulo: Nova Cultural.

SMITH, D. R.; HAZELTON, M. (2008). Bibliometrics, citation indexing, and the journals of nursing. Nursing and Health Sciences, v. 10, n. 4, p. 260-265.

TEECE, D. J.; JORDE, T. M. (1990). Innovation and cooperation: implications for competition and antitrust. Journal of Economic Perspectives, v. 4, n. 3, p. 75-96.

TEECE, D. J. (1992). Competition, cooperation, and innovation Organizational arrangements for regimes of rapid technological progress. Journal of Economic Behavior and Organization, v. 18, n. 1, p. 01-25.

TEIXEIRA, A. A. C. (2014). Evolution, roots and influence of the literature on National Systems of Innovation: a bibliometric account. Cambridge Journal of

Economics, v. 38, n. 1, p. 181-214.

TIDD, J.; BESSANT, J.; PAVITT, K. (2008). Gestão da inovação. Porto Alegre: Bookman.

TSAI, H. (2013). Knowledge management vs. data mining: Research trend, forecast and citation approach. Expert Systems with Applications, v. 40, n. 8, p. 31603173.

URBIZAGÁSTEGUI-ALVARADO, R. (1984). A bibliometria no Brasil. Ciência da Informação, v. 13, n. 2, p. 91-105.

URBIZAGÁSTEGUI-ALVARADO, R. (2002). A Lei de Lotka na bibliometria brasileira. Ciência da Informação, v. 31, n. 2, p. 14-20. 
UTTERBACK, J. M.; ABERNATHY, W. J. (1975). A dynamic model of process and product innovation, Ómega, v. 3, n. 6, p. 639-656.

VON HIPPEL, E. (1976). The dominant role of users in the scientific instrument innovation process. Policy Research, v. 5, n. 3, p. 212-239.

WANG, W.; TANG, J. (2013). Mapping development of open innovation visually and quantitatively: a method of bibliometrics analysis. Asian Social Science, v. 9, n. 11, p. 254-269.

WINTER, S. G. (2003). Understanding dynamic capabilities. Strategic Management Journal, v. 24, n. 10, p. 991-995. 